\title{
Green building project management: obstacles and solutions for sustainable development
}

\author{
Tahereh Khodadadzadeh ${ }^{\mathrm{a}^{*}}$
}

${ }^{a}$ Growing Science, Toronto, Canada \section{H R O N I C L E}

\section{Article history:}

Received: October 1, 2016

Received in revised format: November 16, 2016

Accepted: January 7, 2017

Available online:

January 19, 2017

Keywords:

Green building

Project management

Building sector \begin{abstract}
A B S T R A C T
Building sector is considered as the biggest source of greenhouse gas emissions around the world. Being green, or sustainable, is one of primary issues coming from internal/ external drivers for construction and engineering firms. The green building practice extends and supplement the traditional building design perspectives including economy, utility, durability, and comfort. This paper presents a review on recent advances dedicated on different state-of-art articles in the area of green building. The paper raises serious concern to take the necessary actions for green building development.
\end{abstract}

\section{Introduction}

Green building is normally associated with the structure and the implementation of processes which are environmentally responsible and resource-efficient in a building's life-cycle from design, construction, operation, maintenance, renovation, to demolition (Maltzman \& Shirley, 2011). Green building design includes locating the balance on both homebuilding and the sustainable environment. This needs more cooperation of the design team, the architects, the engineers, and the client at different stages of project (Kubba, 2010). The green building practice expands and contributes the classical building design associated with economy, utility, durability, and comfort (Ji \& Plainiotis, 2006; Qi et al., 2011). Green building includes several components including Energy Efficiency and Renewable Energy, Water Efficiency, Environmentally Preferable Building Materials and Specifications, Waste Reduction, Toxics Reduction, Indoor Air Quality and Smart Growth and Sustainable Development (Shi et al., 2016). Fig. 1 shows different components of a typical house which are subject of green building. In 2010 buildings used about $32 \%$ of total global final energy and consumed $19 \%$ of energy-related GHG emissions (Zhang et al., 2017). They also believe that this type of energy use could be doubled or potentially more by mid-century. China is the world's largest energy consumer and $\mathrm{CO}_{2}$ emitter. China

* Corresponding author.

E-mail address: takhodadadzadeh@mail.com (T. Khodadadzadeh) 
has been entering into a period of prosperity for construction, about $1.6-2.0$ billion $\mathrm{m}^{2}$ buildings are constructed each year, which are about $40 \%$ of the world's total new buildings (Zhang et al., 2017). To reduce $\mathrm{CO}_{2}$ emissions from the manufacturing phase of building materials, sustainable structural design has been introduced. In the embodied $\mathrm{CO}_{2}$ emission data implemented recently, the percentage differences in $\mathrm{CO}_{2}$ emission data for concrete and steel found to be 267 and $863 \%$, respectively (Oh et al., 2017).

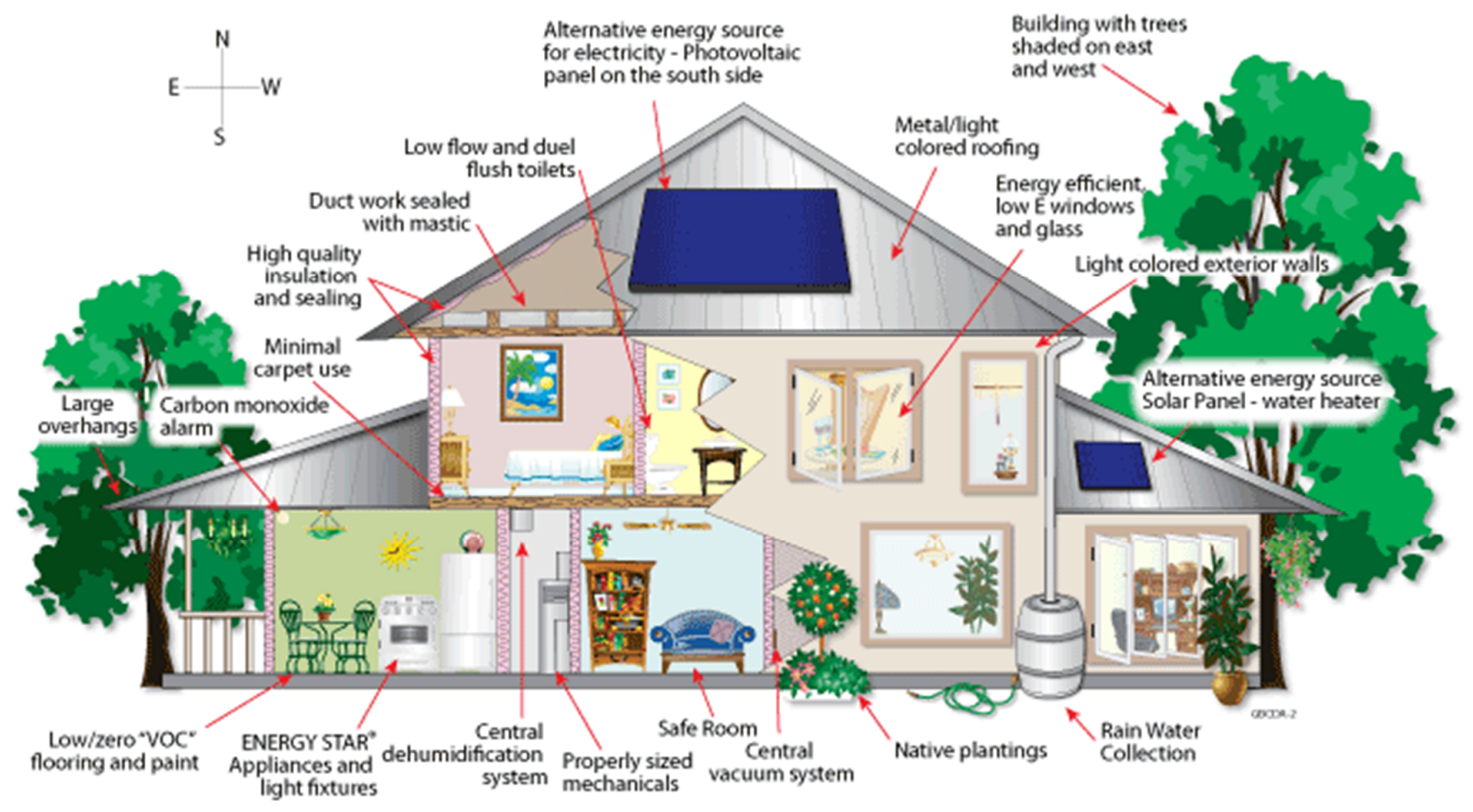

Fig. 1. Schematic of Green Building (Source: http://www.myfloridagreenbuilding.info/ )

\section{Green building}

During the past few years, there have been tremendous efforts on investigating green buildings. The awareness of the heavy effect that the building sector exerts on the natural environment is now widely recognized, leading to a wide spread of tools to control and guide towards building environmental sustainability. The natural environment is considered essentially as an asset to protect. However, nature cannot be protected easily and it is also a key factor to contribute the quality of our built environment and our well-being. Numerous attempts analyzes the positive effect of the introduction of natural elements in building design. However, the use of natural elements in common building practice is still not used commonly and there is a need to promote awareness and use of the potential of the natural elements in design (Oberti \& Plantamura, 2017).

Hwang and Tan (2012) identified common barriers met during management of green construction projects in Singapore's construction industry, and proposed some solutions to overcome the obstacles. They reported that, although project cost was the primary issue among others in green building construction management, there was no paucity in sustainable knowledge in Singapore's construction industry. To handle the cost related issue, the coverage of government incentives needs to be widened to incorporate the usage of green products and technologies. In addition, a project management framework for green building construction has to be developed to remove any existing barriers, possibly promoting adoption of sustainable construction in future projects. 
In the United States, despite the fact that the Leadership in Energy and Environmental Design (LEED) green building rating system has been widely recognized as the national standard for sustainable building design, its evaluation of green buildings is a tedious task and time-consuming because of its complicated process (Nguyen et al., 2015). Such a green building rating process could be accelerated and facilitated by implementing computer technology such as building information modeling (BIM), an innovative, new method for building design, engineering, and construction management that has been used in the architecture, engineering, and construction industry. To enable the green building rating for a building design in BIM applications, building information must be managed in such a way that the knowledge contained in LEED green building criteria could be extracted from the BIM model to support the assessment (Nguyen et al., 2015). Nguyen et al., (2015) presented a building knowledge framework by using the LEED green building criteria. The proposed framework was applied into a BIM platform to reach an automated tool for the rating of a green building design.

Several green rating systems have been developed to evaluate the level of green of the building where there are some similarities and differences among them. Wu and Low (2010) identified the role of project management that is less associated with technology and engineering in developing green building rating systems. They performed an investigation to compare the LEED, the Green Globes, and the BCA Green Mark to find an understanding of current practices, and more specifically, to determine the contribution of project management in reaching green or sustainable construction. The findings imply that project management adopted in green building construction is associated with both the practice and the process. They suggested that the construction and engineering firms consider project management in terms of both the process and the practice when fulfilling requirements of being green.

According to Rumaithi and Beheiry (2016), green building is growing worldwide and in many cases provide a promising rate of return on investment. In addition, there are some advantages associated with green buildings such as lower ecological effect and carbon footprint on the environment, healthier life style for residents and end users, higher service life, less water and energy consumption and less maintenance. The main barrier for a wide adaptation of green and sustainable buildings in the construction industry includes higher initial expenses and the risks involved in such activities, which could be reduced by utilizing a green project management process. Green project management processes may lower the expenses and risks of green projects and raise their competitive advantage versus conventional and less efficient projects. They studied the traditional project management processes used in the United Arab Emirates (UAE) construction industry and discussed the integration of green practices.

Rwelamila et al. (2016) provided a comprehensive review of the existing literature on barriers to sustaining green building initiatives and an argument was constructed on the need to manage these initiatives as projects. Chang et al. (2015) proposed the IGBP-PDRI model based on the life cycle of the engineering to set up different phases of work for process evaluation and it was tested empirically. Preproject planning helps to predict different risks in the development of the project. This helps to make sure the operation efficiency of the project, to the extent that the automated system of the building supported by green construction, which could support sustainable development.

Hwang and $\mathrm{Ng}$ (2013) identified different challenges encountered by project managers who execute green construction projects. They also determined the critical knowledge issues that are necessary to respond to such challenges. Varnäs et al. (2009) illustrates how the environment impacts (EIs) determined in the EIA can be followed up by combining them in the project-environmental management system, the construction contract procurements, and the EMSs and work instructions of the contractor. Yang et al. (2017) studied the feasibility of implementing a multi-objective optimal model on building envelope design (MOPBEM), which involved combining a building envelope energy performance 
model with a multi-objective optimizer. Vyas and Jha $(2016,2017)$ used data envelopment analysis (Charnes et al., 2013) for benchmarking green building attributes to achieve cost effectiveness.

Welsh-Huggins and Liel (2017) presented a framework to evaluate a building's life-cycle performance based on social, environmental and economic effects using probabilistic approaches, taking into account the possible occurrence of an earthquake or other extreme events. The framework was shown through a case study of an office building in Los Angeles, designed with and without various kinds of vegetated (green) roofs, and at risk from varying earthquake hazard scenarios. Their results indicated trade-offs between upfront building costs, material choices, hazard resistance and environmental effect. Xue et al. (2016) explained how to explore the effect of workplace green features, including green certification, ventilation mode, and building morphology, on health perceptions, which includes personal sensation, sensorial assumptions, healing performance based on a survey in Hong Kong and Singapore. The results confirmed the relationship between green features and health perceptions in the workplace environment. In other words, participants from the air-conditioned offices disclosed substantial higher concerns about health issues than the ones from the mixed-ventilated offices.

Wu et al. (2017) analyzed the use of LEED 2009 and studied the credit allocation pattern of 3416 LEED 2009 certified projects. They reported that compared with its previous version LEED v2.2, the point chasing problem in innovation related credits was reduced. Nevertheless, energy-related and materialrelated credits remain a challenge for developers to reach. According to Wu et al. (2017) "LEED 2009 certified projects perform differently in water efficiency at the country level. At the state level, the projects perform differently in water efficiency, energy and atmosphere, material and resources, as well as indoor environmental quality. Varied credit achievement patterns are also identified on cross-certification and cross-sector levels. The study offers a useful guidance for practitioners to achieve relevant certification levels and for regulatory authorities to continuously improve the rating system".

\section{Conclusion}

In this survey, we have reviewed the recent advances on green building design and implementation. We have explained that buildings consumed about $32 \%$ of total global final energy and consumed 19\% of energy-related GHG emissions and would contribute to global warming. Global warming is going to be the number one problem in the world and there is a need to take the necessary action in the world. We hope the results of this survey helps researchers, governmental agencies and policy makers to set new rules for promoting green building design.

\section{Acknowledgement}

The authors would like to thank the anonymous referees for constructive comments on earlier version of this work.

\section{References}

Chang, A. A. P., Chu, B. T. J., Hwang, C. L., \& Lin, C. J. D. (2015, June). Study of scope of intelligent green building project management definition. In Environmental Science and Information Application Technology: Proceedings of the 2014 5th International Conference on Environmental Science and Information Application Technology (ESIAT 2014), Hong Kong, November 7-8, 2014 (p. 7). CRC Press.

Hwang, B. G., \& Tan, J. S. (2012). Green building project management: obstacles and solutions for sustainable development. Sustainable development, 20(5), 335-349. 
Hwang, B. G., \& Ng, W. J. (2013). Project management knowledge and skills for green construction: Overcoming challenges. International Journal of Project Management, 31(2), 272-284.

Ji, Y., \& Plainiotis, S. (2006). Design for Sustainability. Beijing: China Architecture and Building Press. ISBN 7-112-08390-7.

Kubba, S. (2010). Green Construction Project Management and Cost Oversight. Butterworth-Heinemann.

Maltzman, R., \& Shirley, D. (2011). Green Project Management. CRC Press.

Nguyen, T. H., Toroghi, S. H., \& Jacobs, F. (2015). Automated green building rating system for building designs. Journal of Architectural Engineering, 22(4), A4015001.

Oh, B. K., Choi, S. W., \& Park, H. S. (2017). Influence of variations in $\mathrm{CO}_{2}$ emission data upon environmental impact of building construction. Journal of Cleaner Production, 140, 1194-1203.

Oberti, I., \& Plantamura, F. (2017). The inclusion of natural elements in building design: The role of green rating systems. International Journal of Sustainable Development and Planning, 12(2), 217226.

Qi, B. K., Qu, Y., \& Zhao, J. M. (2011). The research on green project management evaluation method of construction. Advanced Materials Research, 291, 3409-3414).

Rumaithi, K. H. A., \& Beheiry, S. M. (2016). A framework for green project management processes in construction projects. International Journal of Sustainable Society, 8(2), 126-144.

Rwelamila, P. M. D., Rwelamila, P. M. D., Purushottam, N., \& Purushottam, N. (2016). Strategic project management as an innovative approach for sustainable green campus buildings in Africa: The need for a paradigm shift. Smart and Sustainable Built Environment, 5(3), 261-271.

Shi, X., Tian, Z., Chen, W., Si, B., \& Jin, X. (2016). A review on building energy efficient design optimization rom the perspective of architects. Renewable and Sustainable Energy Reviews, 65, 872-884.

Varnäs, A., Faith-Ell, C., \& Balfors, B. (2009). Linking environmental impact assessment, environmental management systems and green procurement in construction projects: lessons from the City Tunnel Project in Malmö, Sweden. Impact Assessment and Project Appraisal, 27(1), 69-76.

Vyas, G.S., Jha, K.N., Patel, D.A. (2016). Enhancement of greenness of new construction using the dea. Proceedings of the 32nd Annual ARCOM Conference, ARCOM 2016, pp. 1181-1189

Vyas, G. S., \& Jha, K. N. (2017). Benchmarking green building attributes to achieve cost effectiveness using a data envelopment analysis. Sustainable Cities and Society, 28, 127-134.

Welsh-Huggins, S. J., \& Liel, A. B. (2017). A life-cycle framework for integrating green building and hazard-resistant design: examining the seismic impacts of buildings with green roofs. Structure and Infrastructure Engineering, 13(1), 19-33.

Wu, P., \& Low, S. P. (2010). Project management and green buildings: lessons from the rating systems. Journal of Professional Issues in Engineering Education and Practice, 136(2), 64-70.

Wu, P., Song, Y., Shou, W., Chi, H., Chong, H. Y., \& Sutrisna, M. (2017). A comprehensive analysis of the credits obtained by LEED 2009 certified green buildings. Renewable and Sustainable Energy Reviews, 68, 370-379.

Xue, F., Gou, Z., \& Lau, S. S. Y. (2016). Human factors in green office building design: The impact of workplace green features on health perceptions in high-rise high-density Asian cities. Sustainability, 8(11), 1095.

Yang, M. D., Lin, M. D., Lin, Y. H., \& Tsai, K. T. (2017). Multiobjective optimization design of green building envelope material using a non-dominated sorting genetic algorithm. Applied Thermal Engineering, 111, 1255-1264.

Zhang, Y., Wang, J., Hu, F., \& Wang, Y. (2017). Comparison of evaluation standards for green building in China, Britain, United States. Renewable and Sustainable Energy Reviews, 68, 262-271. 
(C) 2017 by the authors; licensee Growing Science, Canada. This is an open access article distributed under the terms and conditions of the Creative Commons Attribution (CC-BY) license (http://creativecommons.org/licenses/by/4.0/). 